\title{
PEMBERDAYAAN SOSIAL PENYANDANG DISABILITAS NETRA DALAM PEKERJAAN MELALUI PELATIHAN PIJAT MASSAGE DI BRSPDSN WYATA GUNA BANDUNG
}

\author{
Indri Fransiska \\ Program Studi Pendidikan Masyarakat IKIP Siliwangi, Cimahi - Jawa Barat - Indonesia \\ indrifransiska01@gmail.com
}

Received: April, 2021; Accepted: Mei, 2021

\begin{abstract}
This research describes the life of blind people with visual impairments in Bandung City and the empowerment activities they participate in, including massage massage training at BRSPDSN Wyata Guna Bandung. This study used a descriptive qualitative method with a life history model. Data collection techniques were carried out through observation and in-depth interviews with blind disabilities and social employees who took shelter in BRSPDSN Wyata Guna Bandung. The results showed that the visually impaired taking part in massage training at BRSPDSN Wyata Guna Bandung aims to increase their knowledge in the world of massage as well as a training tool for them to get a job or open a business in the service world, namely massage. In this activity they get massage skills which then become their mainstay in their livelihood.
\end{abstract}

Keywords: Empowerment, Massage Training, Employment

\begin{abstract}
Abstrak
Penelitian ini menggambarkan kehidupan disabilitas netra di Kota Bandung dan kegiatan pemberdayaan yang mereka ikuti diantaranya pelatihan pijat massage di BRSPDSN Wyata Guna Bandung. Penelitian ini menggunakan metode kualitatif deskriptif dengan model life history. Teknik pengumpulan data dilakukan melalui observasi dan wawancara mendalam dengan disabel netra beserta para pegawai social yang bernaung di BRSPDSN Wyata Guna Bandung. Hasil penelitian menunjukkan bahwa disabilitas netra mengikuti pelatihan pijat di BRSPDSN Wyata Guna Bandung bertujuan untuk menambah pengetahuan mereka dalam dunia massage serta sebagai sarana pelatihan bagi mereka untuk mendapat pekerjaan ataupun membuka usaha dalam dunia jasa yaitu pijat. Di dalam kegiatan itu mereka mendapatkan keter $\neg$ ampilan memijat yang kemudian menjadi andalan mereka dalam penghidupan.
\end{abstract}

Kata Kunci : Pemberdayaan, Pelatihan Pijat, Pekerjaan

How to Cite: Fransiska, I. (2021). Pemberdayaan Sosial penyandang Disabilitas Netra dalam Pekerjaaan Melalui Pelatihan Pijat Massage di BRSPDSN Wyata Guna Bandung. Comm-Edu (Community Education Journal), 4(2), 57-62.

\section{PENDAHULUAN}

Disabel atau disabilitas menurut lembaga kesehatan dunia (World Health Organization) merujuk pada kondisi gangguan atau keterbatasan dalam aktivitas yang dialami oleh individu yang berdampak pada terbatasnya partisipasi mereka dalam kegiatan sehari-hari di masyarakat. Gangguan itu biasanya berasal dari fungsi atau struktur tubuh individu. Disabilitas dibagi beberapa jenis, yaitu: disabilitas fisik, disabilitas mental, disabilitas intelektual, disabilitas sensorik, dan disabilitas perkembangan (World Health Organization, 2011). Badan Pusat Statistik mencatat sejumlah 10.000.000 penyandang disabilitas di 
Indonesia pada 2015. Dari jumlah tersebut, 1.773 .290 jiwa atau 17.7\% adalah penyandang disabilitas netra (Badan Pustaka Statistik, 2015).

Di masyarakat, para penyandang disabilitas, termasuk disabilitas netra masih belum mendapatkan kesempatan hidup yang sama dengan orang non-disabilitas. Bahkan mereka seringkali mengalami stigma dan diskriminasi. Banyak warga masyarakat yang menganggap disabilitas sebagai 'kutukan' ataupun 'malapetaka' bagi individu dan keluarga yang mengalaminya. Ironisnya, anggapan demikian tak jarang justru muncul dari keluarga dekat. Akibat dari anggapan ini, para penyandang disabilitas seringkali mengalami nasib kurang menyenangkan; misal dikucilkan, dikirim ke panti, atau yang terburuk, dipasung. Jikalau para disabilitas masih tinggal bersama keluarganya pun, hak mereka, seperti warisan, seringkali diambil oleh anggota keluarga lain dengan dalih "para disabilitas tidak akan dapat mengelolanya" (Rappler, 2016). Selain itu, para disabel seringkali ditelantarkan oleh keluarga mereka. Padahal, di dalam Undang-undang nomor 8 tahun 2016 telah disebutkan bahwa keluarga tidak dapat berbuat semena-mena pada penyandang disabilitas, atau menyerahkan anggotanya yang menyandang disabilitas fisik ataupun mental dengan mudahnya ke panti. Keluarga harus merawat para penyandang disabilitas agar mendapatkan rehabilitasi klinis yang layak dengan didampingi tenaga ahli dan terapis. Selain merawat dan merehabilitasi, keluarga juga harus selalu memberi dukungan dan motivasi pada para disabel. Sebab, para disabel, terutama disabel fisik, seringkali merasa depresi ketika menyadari perbedaan kondisi fisik mereka dengan orang lain secara umum.

Motivasi dari keluarga akan membuat para disabel bersemangat menjalani kehidupan. Perhatian pemerintah pada hak-hak penyandang disabilitas saat ini memang belum cukup memadai, terutama bagi disabilitas netra. Program pemerintah bagi disabilitas netra pun masih sangat terbatas. Salah satunya program dari Kementerian Sosial Republik Indonesia berupa pendirian BRSPDSN (Panti Sosial Bina Netra). Program ini bertujuan untuk memberikan keterampilan kepada penyandang disabilitas netra sehingga mereka mampu mandiri dan berperan aktif dalam kehidupan bermasyarakat (Wulandari, 2018).

Di Kota Bandung, BRSPDSN Wyata Guna adalah salah satu BRSPDSN yang berada di bawah Dirjen Pelayanan dan Rehabilitasi Sosial Departemen Sosial Republik Indonesia. BRSPDSN ini memberikan layanan rehabilitasi dan perlindungan sosial bagi disabel netra yang meliputi: bimbingan sosial, bimbingan mental, bimbingan fisik, bimbingan keterampilan, dan bimbingan lanjut agar para disabilitas netra dapat mencapai kesetaraan dan kemandirian, serta mampu berperan aktif dalam kehidupan bermasyarakat. BRSPDSN ini juga mempunyai program khusus yang bertujuan memberdayakan disabilitas netra.

Penelitian ini akan mengulas kehidupan para disabilitas netra di Kota Bandung yang tergabung dalam BRSPDSN Wyata Guna; kegiatan pemberdayaan yang mereka ikuti; serta dampak dari kegiatan itu pada kehidupan para disabilitas netra.

Kamus Besar Bahasa Indonesia (KBBI) mendefinisikan tunanetra 'tidak dapat melihat'; atau merujuk pada individu yang tidak memiliki kemampuan untuk melihat. Pertuni (Persatuan Tuna Netra Indonesia) mendefinisikan tunanetra sebagai individu yang tidak memiliki penglihatan sama sekali atau mengalami kebutaan total. Sementara itu, Nakata (2003) mendefinisikan disabel netra sebagai orang yang mempunyai ketajaman penglihatan kurang dari $0,3(60 / 200)$ atau mereka yang mempunyai tingkat kelainan fungsi penglihatan yang tinggi. Disabel netra memiliki kesulitan secara signifikan untuk membaca tulisan atau ilustrasi meskipun dengan mempergunakan alat bantu kaca pembesar (Rahardja, 2010). 
Kondisi tunanetra memiliki ciri-ciri 1) ketajaman penglihatan yang kurang dari ketajaman yang dimiliki orang yang dapat melihat secara normal; 2) mengalami kekeruhan pada lensa mata atau terdapat cairan tertentu pada lensa mata; 3) memiliki posisi mata sulit dikendalikan oleh syaraf otak; 4) mengalami kerusakan susunan syaraf otak yang berhubungan dengan penglihatan (Sutjihati \& Somantri, 2006). Selain ciri-ciri tersebut, (Hosni, 1995) menyebutkan bahwa seorang tunanetra: 1) hanya mengenal bentuk dan obyek (sedikit sisa penglihatan); 2) hanya dapat menghitung jari dari berbagai jarak; 3) tidak dapat melihat tangan yang digerakkan; 4) hanya dapat membedakan gelap, terang atau persepsi cahaya tetapi masih dapat menunjuk sumber cahaya; dan 5) tidak mempunyai persepsi cahaya (buta total).

Faktor yang dapat menyebabkan kondisi tuna netra dapat berasal dari faktor internal dan faktor eksternal. Faktor internal merujuk pada faktor bawaan individu sejak individu berada dalam kandungan. Faktor kelainan gen, kondisi kesehatan ibu, kekurangan gizi, atau keracunan obat merupakan faktor internal yang dapat menjadi penyebab kondisi tunanetra sejak lahir. Faktor eksternal merujuk faktor yang menyebabkan individu mengalami tunanetra setelah lahir. Faktor itu antara lain kecelakaan, terkena penyakit mata, pengaruh alat bantu medis, terkena virus, kurang gizi pada masa perkembangan, kurang vitamin, sakit panas tinggi, dan keracunan (Sutjihati \& Somantri, 2006).

Secara konseptual, pemberdayaan atau pemberkuasaan (empowerment) berasal dari kata "power" yang artinya kekuasaan atau keberdayaan. Tujuan pemberdayaan adalah membentuk kemampuan orang atau kelompok rentan dan lemah untuk memiliki kekuatan atau kemampuan dalam hal: 1) memenuhi kebutuhan dasarnya sehingga mereka memiliki kebebasan untuk mengemukakan pendapat, bebas dari kelaparan, bebas dari kebodohan, dan bebas dari kesakitan; 2) menjangkau sumber-sumber produktif yang memungkinkan mereka dapat meningkatkan pendapatannya dan memperoleh barang-barang dan jasa-jasa yang mereka perlukan; dan 3) berpartisipasi dalam proses pembangunan dan keputusan-keputusan yang mempengaruhi mereka (Suharto, 2014).

Pemberdayaan juga bertujuan membentuk individu dan masyarakat menjadi mandiri. Kemandirian tersebut meliputi kemandirian berpikir, bertindak, dan mengendalikan apa yang mereka lakukan tersebut. Kemandirian dicapai melalui proses belajar secara bertahap (Sulistiyani, 2006). Di dalam proses pemberdayaan, manusia merupakan subyek dari dirinya sendiri. Di dalam proses ini, manusia berupaya agar berdaya, mendorong atau memotivasi diri agar mempunyai kemampuan atau keberdayaan untuk menentukan pilihan hidupnya.

Kegiatan pemberdayaan dilaksanakan secara menyeluruh, mencakup aneka bidang: ekonomi, politik, dan sosial budaya. Pemberdayaan di bidang ekonomi merujuk pada upaya menjadikan individu atau masyarakat memiliki ekonomi yang kuat, besar, mandiri, dan berdaya saing tinggi dalam mekanisme pasar yang besar, di mana terdapat proses penguatan golongan ekonomi lemah. Pemberdayaan di bidang politik merujuk pada upaya menguatkan kemampuan individu atau masyarakat dalam mengambil keputusan yang menyangkut kehidupan mereka sendiri; dan di dalam konteks kehidupan berbangsa dan bernegara. Pemberdayaan masyarakat di bidang sosial budaya merujuk pada upaya menguat $\neg$ kan individu atau masyarakat melalui peningkatan, penguatan, dan penegakan nilai-nilai, gagasan, dan norma-norma, serta mendorong terwujudnya organisasi sosial yang mampu memberi kontrol terhadap perlakuan-perlakuan politik dan ekonomi yang jauh dari moralitas (Moeljarto, 1995). 
60 Fransiska, I. Pemberdayaan Sosial Penyandang Disabilitas Netra dalam pekerjaan Melalui Pelatihan Pijat Massage di BRSPDSN Wyata Guna Bandung

\section{METODE PENELITIAN}

Metode penelitian menggunakan pendekatan kualitatif dengan metode deskriptif. Metode ini dipilih karena data yang dkumpulkan dalam penelitian ini berupa penjabaran yang diuraikan dengan kata-kata. Penelitian ini juga bermaksud untuk memahami, mengungkap dan menjelaskan berbagai gambaran atas beberapa fenomena-fenomena yang ada di lapangan dan kemudian dirangkum menjadi kesimpulan deskriptif berdasarkan data dari hasil penelitian yang dikumpulkan sendiri oleh peneliti. Salah satu ciri dari penelitian kualitatif adalah deskriptif, data yang dikumpulkan berupa penjabaran yang diuraikan dengan kata-kata dan gambar (Azzahro \& Kurniadi, 2017).

Sedangkan instrument penelitian yang digunakan dalam penelitian ini sebagai berikut: Pertama, studi dokumentasi adalah sebuah dokumen yang di dalamnya ada catatan peristiwa yang sudah berlalu. Dokumen bisa berbentuk tulisan, gambar atau karya-karya monumental dari seseorang, dokumen yang berbentuk tulisan msalnya catatan harian, sejarah kehidupan (life histories), ceritera, bografi, peraturan, kebijakan. Dokumen yang berbentuk gambar misalnya foto, gambar hidup, sketsa dan lain-lain. Dokumen yang berbentuk karya misalnya karya seni, yang dapat berupa gambar, patung, film dan lain-lain (Sugiyono, 2018). Kedua, wawancara adalah pertemuan dua orang untuk bertukar informasi dan ide melalui tanya jawab, sehingga dapat dikontruksikan makna dalam sebuah topik tertentu (Sugiyono, 2018).

Objek penelitian pada saat pengumpulan data melalui wawancara dilakukan kepada 5 orang yang terdiri dari 3 orang disabilitas netra yang sedang mengikuti pelatihan pijat massage dan 2 orang pegawai dari BRSPDSN Wyata Guna Bandung.

\section{HASIL DAN PEMBAHASAN}

BRSPDSN Wyata Guna adalah sebuah panti sosial bina netra yang berada di Jalan Pajajaran No. 52 RT/RW 06/03 Kelurahan Pasir Kaliki, Kecamatan Cicendo, Kota Bandung. Panti ini merupakan lembaga binaan Kementerian Sosial RI dan merupakan BRSPDSN terbesar di Indonesia. BRSPDSN Wyata Guna berperan dalam memberikan bimbingan, pelayanan, dan rehabilitasi sosial yang bersifat kuratif, rehabilitatif, dan promotif dalam bentuk bimbingan pendidikan dasar, fisik, mental, sosial, dan pelatihan keterampilan. Selain itu,BRSPDSN Wyata Guna juga memberikan re-sosialisasi bimbingan lanjut bagi para penyandang disabilitas netra agar mampu mandiri dan berperan aktif dalam kehidupan bermasyarakat. Kegiatan re-sosialisasi yang disediakan BRSPDSN Wyata Guna berupa pelatihan kemandirian, praktik belajar kerja, bimbingan pembinaan bantuan, stimulan usaha ekonomi produktif, dan penyaluran tenaga kerja. BRSPDSN Wyata Guna juga melakukan pengkajian dan penyiapan standar pelayanan, pemberian informasi, dan rujukan bagi disabel netra.

Di BRSPDSN Wyata Guna terdapat aneka program kegiatan bagi disabel netra. Para disabel netra dapat bergabung dalam aneka program kegiatan di BRSPDSN Wyata Guna dengan cara melakukan registrasi dan mengikuti proses seleksi. Sebagai bagian dari proses seleksi, petugas BRSPDSN Wyata Guna melakukan kunjungan rumah disabel netra guna melakukan pengamatan pada kehidupan sehari-hari disabel netra dan diskusi dengan keluarganya untuk memastikan bahwa disabel netra layak mengikuti program. Disabel netra yang mengikuti program kegiatan di Wyata Guna diberi fasilitas tempat tinggal di asrama dan tinggal di tempat tersebut selama kegiatan berlangsung. Lembaga ini juga memiliki program bimbingan lanjutan yang bertujuan memantau disabel netra setelah selesai mengikuti kegiatan pelatihan untuk melihat sejauh mana mereka menerapkan keterampilan yang telah dimiliki. Selain ke- 
giatan di dalam lembaga, BRSPDSN Wyata Guna juga memiliki kegiatan pelayanan di luar panti yang berupa penjangkauan (outreach), family care dan day care.

BRSPDSN Wyata Guna juga menyediakan layanan pendidikan luar biasa bagi disabel netra. Layanan pendidikan yang disediakan oleh BRSPDSN Wyata Guna berupa sekolah luar biasa tingkat dasar hingga tingkat menengah. Pada tingkat SMA, SLB Wyata Guna memiliki dua jurusan, yaitu bahasa dan seni musik. Proses belajar mengajar di sekolah ini menggunakan huruf braile.

\section{KESIMPULAN}

Disabel netra disebabkan oleh faktor internal (gen atau keturunan), dan faktor eksternal (kecelakaan). Perbedaan faktor yang menyebabkan disabilitas, memengaruhi cara penyandang disabilitas netra dalam koping strategi mereka. Disabel netra sejak lahir, cenderung lebih pasrah dalam menerima kondisi disabilitas mereka; sedangkan disabel netra akibat kecelakaan seringkali mengalami depresi hebat terkait disabilitas mereka. Koping strategi yang dilakukan oleh disabel netra adalah mencari pengobatan dan memperkuat aspek keagamaan dalam diri mereka. Penguatan aspek keagamaan di dalam diri disabel netra berperan dalam proses penerimaan diri disabel netra sehingga mereka mampu menjalankan hidup dan tidak menutup diri dari lingkungan. Pengobatan yang dilakukan berupa pengobatan non-medis seperti terapi hyperbaric, akupresur, dan pengobatan dengan menggunakan jasa "orang pintar", sedangkan pengobatan medis berupa operasi mata. Kondisi disabel netra yang memi $\neg$ liki kekurangan menyebabkan mereka menjadi kelompok yang tidak berdaya. Para disabel netra mengikuti kegiatan pemberdayaan yang dilakukan oleh BRSPDSN Wyata Guna sehingga dapat lebih berdaya. Kegiatan pemberdayaan yang diikuti berupa pelatihan keterampilan massage praktis dan keterampilan membuat sapu serta keset. Keterampilan tersebut dapat digunakan oleh para disabel netra untuk bekerja. Beberapa disabel netra memperoleh pendapatan yang lebih besar setelah mengikuti pelatihan yang diberikan oleh BRSPDSN Wyata Guna, sehingga mereka menjadi lebih berdaya.

\section{DAFTAR PUSTAKA}

Badan Pustaka Statistik. (2015). Penduduk Indonesia : Hasil Survei Penduduk Antar Sensus 2015. Jakarta: Badan Pusat Statistik.

Hosni, I. (1995). Buku Ajar Orientasi dan Mobilitas. Jakarta: Departemen Pendidikan Nasional, Direktorat Jenderal Pendidikan Tinggi, Direktorat Pembinaan Pendidikan Tenaga Kependidikan dan Ketenagakerjaan Perguruan Tinggi.

Moeljarto, T. (1995). Politik Pembangunan. Yogyakarta: Tiara Wacana.

Rahardja, D. (2010). Pendidikan Luar Biasa dalam Perspektif Dewasa Ini. Jassi Anakku, 7668.

Rappler. (2016, Maret 18). RUU Disahkan, Hak Penyandang Disabilitas Dijamin Un $\neg$ dangundang. Diambil kembali fari Rappler.com:https://www.rappler.com/indone $\neg$ sia/126291-dpr-sahkan-uu-penyandangdis $\neg$ abilitas.

Sugiyono. (2018). Metode Penelitian Kuantitatif, Kualitatif, dan R\&D. Bandung: CV. Alfabeta

Suharto, E. (2014). Membangun Masyarakat Memberdayakan Rakyat: Kajian Strategis Pembangunan Kesejahteraan Sosial dan Pekerjaan Sosial. Bandung: PT. Refika Utama.

Sulistiyani, A. T. (2006). Kemitraan dan Model-Model Pemberdayaan. Yogyakarta: Gaya Media. 
62 Fransiska, I. Pemberdayaan Sosial Penyandang Disabilitas Netra dalam pekerjaan Melalui Pelatihan Pijat Massage di BRSPDSN Wyata Guna Bandung

Sutjihati, T., \& Somantri. (2006). Psikologi Anak Luar Biasa. Bandung: Refika Aditama.

Theresia, A., Andini, K., Nugraha, P. G., \& Mardikanto, T. (2014). Pembangunan Berbasis Masyarakat : Acuan Bagi Praktisi, Akademisi dan Pemerhati Pengembangan Masyarakat. Bandung: Alfabeta.

World Health Organization. (2011). Understanding Disability. Malta: World Health Organization.

Wulandari, L. (2018). Panti Sosial Bina Netra di Kota Pontianak. Jurnal Online Mahasiswa S1 Teknik Untan, 82-96. 